\title{
Cultural Nuances in Work Attitudes and Behaviors: Towards a Model of African Work Culture
}

\author{
Elizabeth I. Olowookere' \\ Benedict C. Agoha ${ }^{1}$ \\ Dare O. Omonijo ${ }^{2}$ \\ Jonathan A. Odukoya' \\ Ayotunde O. Elegbeleye ${ }^{1}$ \\ ${ }^{1}$ Department of Psychology, Covenant University, Ota, Nigeria \\ ${ }^{2}$ Department of Student Industrial Experience Scheme, Covenant University, Ota; \\ Department of Sociology, Olabisi Onabanjo University, Ago-Iwoye, Nigeria
}

DOI: https://doi.org/10.36941/ajis-2021-0056

\section{Abstract}

This study explored managers' perception of the work behaviors and attitudes of Nigerian workers with reference to Nigeria's cultural orientation and the global culture. It compared Japan, USA and Nigeria on Hofstede's cultural dimensions, work culture and organizational outcomes. Descriptive survey design and purposive sampling technique were used in data collection. A total of 131 managers (74 males and 57 females) from manufacturing organizations in Ota, Ogun State were interviewed. The structured interview comprised of 12 statements on work attitudes and behaviors to which respondents agreed or disagreed and made remarks. Four research questions were asked and answered using frequency distribution. The result showed that greater percentage of managers perceived Nigerian workers to require close supervision, sanctions and coercion in driving compliance with organizational rules. Workers were also perceived to be motivated mostly by pay, rewards and benefits. However, only about half of the respondents agreed that Nigerian workers are selfcentered and individualistic. Lastly, they perceived that given the right circumstances, Nigerian workers are highly resourceful and capable of participative decision-making and mutual responsibility. This study concluded that Nigeria as well as Japan have collectivist cultures while America has individualistic culture. Although collectivism has paid off as evinced in the successes of Japanese companies, Nigerian organizations, like many others in Africa, have been victims of acculturation with adverse consequences for organizational growth. Hence, a model of African work culture was recommended, one that should not jettison indigenous cultures, but ensure an effective blend with global best practices.

Keywords: Work Behaviors, Work Attitude, Culture, Japan, America, Nigeria, Africa

\section{Introduction}

Humans are social animals interacting within specific societies with shared identities, ideologies, languages and a goal to ensure continued survival and sustainability among others. The interactions 
among these individuals as argued by some authors are essentially guided by prescribed and preserved codes of conduct and values referred to as culture (Omonijo \& Anyaegbunam, 2020). Culture has been described in several ways by some authors but their perspectives on culture lies in the generally accepted way of life of a group of people that is passed down from generation to generation through the process of socialization (Adetola, Ogunbote, Omonijo \& Odukoya. 2019). It is the shared characteristics that defines certain groups of people and distinguishes them from others. These shared patterns of behaviors include language, social habits, belief system, mode of dressing, behaviors, economic systems, politics, music and arts among others.

Although every society has its own cultural peculiarities as regards different aspects of human endeavors, the quest for environmental and economic sustainability has fostered interdependence and unity across societies, resulting in an interaction of cultures and the rise of a unified culture. Asikaogu (2018) suggested that this global culture is an extension of the western culture to other nations of the world as the acceptable way of behavior. Advances in technology have further united the world into a global village, it is now easy for businesses to operate globally and benchmark with competitors on global trends, best practices and profitability.

Every organization is in a rat race to retain global relevance, adapt to the rapidly changing market trends and gain competitive advantage over rival organizations. A major means of achieving this feat is the continuous improvement of the organizations' people, products, processes and productivity. The people element has been considered the most important because it facilitates the effective coordination of the other elements (Pfeffer, 1998). Therefore, employee behaviors and attitudes to work are crucial to effective organizational functioning. In corroboration, Jahangir, Akbar and Haq (2004) asserted that every organization requires employees' demonstration of positive work behaviors (often referred to as organizational citizenship behaviors) for their continued survival and overall effectiveness.

The global culture affects behaviors in different contexts including the workplace. This is because the pace of globalization makes cultural isolation impossible (Rudd \& Lawson, 2007).According to Asikaogu (2018), globalization is about economic integration, the transfer of policies across borders and the transmission of knowledge among other things.In the quest for profitability and competitiveness, organizations have adopted different policies and global best practices to facilitate the demonstration of coveted work behaviors regardless of the peculiarities of their contexts and cultural orientations.

Traditionally, Africans are known for their sense of unity and value for kinship, brotherhood, egalitarianism and cooperation. The African spirit may be described as one that exudes oneness, strength, and doggedness but this has been watered down by the western culture through the process of globalization. For instance, despite the collectivist nature of the Nigerian people, the Nigerian work culture may be described as individualistic, mirrored after cultures like that of the United States and characterized by self-seeking behaviors and attitudes in which each employee is primarily out to meet his/her personal needs at all cost (Olowookere, 2015). This individualistic culture may be linked to the apathetic nature of the Nigerian workers (Akinbode \& Fagbohungbe, 2012) and their constant conflict with the management. Many managers in Nigerian organizations consider employees as naturally lazy, unambitious, motivated by pay, selfish and not disposed to taking responsibilities. Consequently, these managers further create organizational inefficiencies throughtheir constant use of sanctions and control as means to drive compliance in the workplace.

The Japanese also have a collectivist culture and the work culture is one that has been associated with employees' loyalty and commitment to organizational effectiveness. The Japanese culture emphasizes family collectivism and interpersonal harmony which engenders voluntary demonstration of positive work behaviors among employees. All organizations covet these behaviors but cannot demand such from their employees. They can only cultivate these behaviors through favorableorganizational culture and practices. Consequently, the current study explored managers' perception of the work behaviors and attitudes of Nigerian workers, compared Japan, USA and Nigeria on Hofstede's cultural dimensions andproposeda model of African work culture.

Given this, the study intends to specifically: (i) ascertain managers' perception about the need for 
force and sanctions in driving compliance among Nigerian workers; (ii) determine managers' perception about the individualistic nature of Nigerian workers; (iii) determine managers' perception on pay, rewards and benefits as the primary motivators among Nigerian workers; (iv) explore managers' opinion on the capacity, resourcefulness and potentials of the Nigerian workers; and compare Japan, USA and Nigeria on Hofstede's cultural dimensions and propose a model of African work culture.

\section{Literature Review}

\subsection{The concept of Culture}

Many scholars have attempted a concise definition of the word "culture".According to Hofstede (2011), culture is the collective programming of the mind which distinguishes a category of people from another. Similarly, Weaver (2005) defined culture as the way of life of a group of people transmitted through learning from one generation to the next. A crucial aspect missing from these definitions of culture is its transmission across contexts and boundaries. Owing to globalization, cultural practices and values are now being adopted across nations and continents of the world. In support, Bannon, Guy, Al-Omari, Reed, Pooley and White (2003) noted that businesses no longer stay in a single culture, they adapt and inculcate best practices across the globe into their corporate culture.

Corporate culture refers to established organization-wide beliefs, values, ideals and behavioral patterns initiated and endorsed by the management of the specific organizations. Odogwu (2012) asserted that corporate culture creates a given atmosphere of business operations and to a large extent determines the relationship between employers, employees and customers. According to Hofstede (1991), culture can be likened to an onion that has several layers. Each layer represents internalized culture of the different groups to which individuals belong e.g. family, ethnic groups, religious groups etc.In the work setting, the corporate culture overrides individual background characteristics, orientations and affiliations (cultural, ethnic, religious or professional) with emphasis on personorganization fit.

\subsection{Hofstede's cultural dimensions Theory}

Hofstede's cultural dimension theoryis a widely accepted model for explaining national culture. According to Hofstede (1991) there are six cultural dimensions on which nations are ranked. These dimensions are as follows: Power Distance Index, Individualism versus Collectivism; Masculinity versus Femininity; Uncertainty Avoidance; Long-Term Orientation versus Short-Term Orientation; and Indulgence versus Restraint. In some studies, cultural orientations have been found to impact upon organizational practices and outcomes (Oludayo \& Omonijo, 2020). Studies have also shown that the most outstanding organizations in years past are of American and Japanese origin, this explains the reason for comparing the Nigerian cultural dimensions with those of America and Japan.

Power Distance refers to the extent to which some members of a group agree to the superiority of the other members and the unequal distribution of power in that regard. This is the type of inequality that is advocated by the ruled and not the ruler. It describes how well the leaders and followers of any society support power inequality. Power distance is a reality across cultures but vary from one culture to another. It may be high in some cultures and low in others. The gap between the ruled and the ruler determines whether the power distance is high or low. When there is a wide gap, the power distance is high and vice versa. The Nigerian culture may be described as a high power distance culture, one that celebrates hierarchy and formalities between the superiors and the subordinates. In this culture, employees usually are not a part of the target setting decisions. On the contrary, the Western cultures are characterized by low power distance (Brewster et al., 2011, cited in Mbah \& Kuye, 2019) where goal setting involves participative decision making between the managers and their subordinates. Likewise, Japan did not meet the criteria for high power distance, rather it may be considered moderate in its power distance and also operates participative decision making. 
The Individualism versus Collectivism dimension refers to the degree of solidarity and commitment that exist among members of a society. Cultures that are low on solidarity and commitment to shared goals may be regarded as individualistic cultures while those high on these qualities represent the collectivist cultures. Individualistic cultures are competitive while collectivist cultures are communal in nature. The result from the world ranking on the Individualism versus Collectivism dimension revealed a score of 91 for America, 30 for Nigeria and 46 for Japan,where the mean score was 43 (Hofstede, 2001). The higher the score, the higher the individualism and the lower the collectivism. Consequently,America was categorizedas one of the highly individualistic countries while Nigeria and Japan as collectivist countries(Hofstede, 2001; Hofstede, 1991).In the American context, employees' compensation and benefits are performance driven while Nigeria and Japan use uniform payment scheme.

The Masculinity versus Femininity dimension describessocieties'tendency to recommend and support traditional males and female roles. Hofstede (2011) noted that males are stereotypically viewed as aggressive and ambitious while the females are seen as compassionate and emotional. Nigeria is one of the masculine (male dominated) societies, where females do not stand equal chance in attaining leadership positions across sectors. In the world ranking on this dimension, Japan ranked highest with a score of 95, followed by America with a score of 62 and lastly Nigeria with a score of 60 . All three countries have high masculine cultures with scores that exceeded the World average of 50.

The Uncertainty Avoidance shows the extent to which cultures accommodate or tolerate ambiguity. The maintenance of strict rules, law and order in a society may serve as an indication of high uncertainty avoidance index (Hofstede, 1991). Based on the world ranking, America ranked 43rd, Nigeria $34^{\text {th }}$ and Japan 7 th position (Hofstede, 2001). By implication, Japan has very lowtolerance for ambiguity and may have standardized procedures, rules and policies that governs the actions of its citizens. On the contrary, America and Nigeria havehigh tolerance for ambiguity and may be quite flexible with their procedures and policies (Hofstede, 2001). Furthermore, Hofstede's empiricalliterature, did not label Nigeria as either high or low on the uncertainty avoidance dimension, which means thatthe position of Nigeria on this dimension is not clearly defined.

Indulgence versus Restraintdimension explains the level of control that cultures have on the gratification of desires. Minimal control makes the culture indulgent, while strict control produces restraint culture. Indulgent cultures are marked by fun, pleasures and happiness while the restraint cultures are the opposite. Indulgent cultures encourage recreation, celebration and relaxation. On the other hand, restraint cultures are too serious in their approach to work and life in general. Nigeria is an example of an indulgent culture, the people are known for happiness, fun-seeking and optimism even in the face of untold hardship. Comparing Nigeria, America and Japan on this dimension, Nigeria scored highest, followed by America and then Japan.Like Japan, most countries in Asia and Eastern Europe have restraint culture (Mbah \& Kuye, 2019).

Lastly, the Long Term versus Short Term dimension is an indicator of where a culture's interest lies - in the present or in the future. Cultures with long term orientation are far-sighted and concerned about the future while those with short term orientation live and plan for the here and now. The higher the score on this dimension the more the long term orientation. Japan scored highest on this dimension, followed by Nigeria and then America. By implication, Japan is a long-term oriented country compared to Nigeriaand America. (Hofstede, 2001). This means that Japan plans ahead, which explains its inventiveness and technological inclinations.

On the whole, Nigeria and America's cultural inclinations are similar in the following areas: being indulgent, having short term orientation, masculine inclination, and low uncertainty avoidance. Nigerians, like Americans are fun-loving, free spirited people who emphasize gender differences, and appear to deal with issues as they unfold. However, these two cultures are different on the grounds of communalism and power distance. Nigerians are naturally their brothers' keeper; they love to look after one another and do things in common. Furthermore, they have high regard for hierarchy. Americans on the other hand, are highly individualistic with little or no regard for hierarchy. Nigeria and Japan are only similar in their communal lifestyle and their masculinity orientation. Like the 
Americans, Japanese are not so much into hierarchy. Across the three cultures, masculinity is the only dimension that is shared by all.

These cultural orientations affect work values and behaviors and consequently organizational, national and global outcomes. Although organizational policies and processes are reflections of adopted cultural practices, there is a need to blend employees' indigenous cultural orientation with those of theirorganizations for maximum productivity and effectiveness.

\subsection{McGregor's Theory $X$ and Theory $Y$}

McGregor in the 196os proposed Theory $\mathrm{X}$ as a description of the management style that emanated from the scientific management theory proposed by Frederick Taylor in the 1800 s. As a fallout of the industrial revolution, the disorganized nature of the industries prompted Frederick Taylor to propose the one best way to organize production for maximum profitability. In his view, employees are mainly concerned with economic gains, and so employment contract should be centered strictly on "work for pay". Management's interest is to enforce compliance with organizational rules and get maximum output from employees for the pay they receive. This is usually achieved through the use of threat and sanctions. The "carrot and stick" notion is a central feature of the scientific management theory.

Theory X explained that this management style is fueled by individualism and utilitarianism. Managers perceived employees to be self-centered, indolent, unaspiring andapathetic. All the employees care about is how to secure their own interest and personal gains even at the detriment of the organization.In response to these perceptions, managersresorted to the use of force and economic incentives to improve performance. On the part of the employees, they respond to this management style with forced compliance;they merely meet specified work targets with no attempt at going the extra mile to achieve organizational effectiveness (Wysocki \& Kepner, 2000).

As a reaction to Theory X, McGregor (1960) proposed Theory Y as the ideal standpoint and management perspective on employees. Employees are perceived as industrious, ambitious, selfmotivatedand resourceful. They are believed to enjoy work the same way they enjoy play. This Theory suggests that employees will perform at their best when provided with the right conditions.

\subsection{Ouchi's Theory Z}

Ouchi (1981) proposed Theory Zas his explanation for Japanese management style.The emphasis of this Theory is partnership, loyalty and teamwork. The employees are treated as stakeholders; they see the organization as a family of which they are members. The employees' welfare is taken as top priority and they in turn commit themselves to the organization. Ouchi (1981) compared American organizations to Japanese organizations. He investigated the reasons Japanese organizations seemed to thrive better than their American counterparts and found that the difference was due to adopted management style and cultural practices.

Japanese employees see themselves as one with the organization; they are devoted to the effectiveness of these organizations with the confidence that the organizations have their best interest at heart. Japanese organizations trust their employees to perform their duties to the best of their abilities and even beyond the call of duty without any form of surveillance. On the other hand, American organizations based their management styles on their individualistic culture. They encourage competition among employees and monitor compliance with organizational processes. The implication of this is that these employees may be more interested in outshining one another at the expense of shared organizational goals.

Owing to globalization, Nigerian organizations have adopted different management practices of American origin. Although they have a collectivist culture at the national level, they seem to be individualistic in their work or corporate culture. Nigeria is one nation that practices individualism in collectivism. One may assume that Nigerians tilted towards American work practices because of the other shared cultural dimensions such as being indulgent and focusing on the here and now. 
Yet all organizations, whether of Japanese, American or Nigerian origin desire to have employees who will see themselves as stakeholders in the organization and work wholeheartedly towards the achievement of shared goals. The question here is "Are Nigerian employees individualistic or collectivist? What should the Nigerian work culture, by extension African work culture look like?

\section{Method}

The descriptive survey design and purposive sampling technique were used in data collection. A total of 131 managers (74males and 57 females) from manufacturing organizations in Ota, Ogun State were interviewed and made to indicate their opinions in response to statements on employees' work behaviors from the managers' perspective. The structured interview comprised of 12 statements on work attitudes and behaviors to which they agreed or disagreed and made remarks.

The statements were based on Theory $\mathrm{X}$ and Theory Y assumptions about employees, the number of respondents that agree to each of the statements give credence to the statement. A statement is accepted as true when majority of the respondents agree to it.

\section{Results}

Four research questions were raised and answered using frequency distribution and the results are presented as follows: Research question one, "What is managers' perception about the need for force and sanctions in driving compliance among Nigerian workers?" was answered using five statements measuring the need for sanctions and coercion in Nigerian organizations and the result of the frequency distribution revealed that the overall perception of the managers is that organizations in Nigeria need sanctions and coercion to enforce compliance with organizational rules and processes.

Research question two, "What is managers' perception about the individualistic nature of Nigerian workers?" was answered using two statements on the individualistic nature of the employees and the result revealed that about half of the respondents agreed that Nigerian workers are selfcentered. Furthermore, Research question three, "What is managers' perception on pay, rewards and benefits as the primary motivators among Nigerian workers?" was answered from a statement on pay as the primary motivator among Nigerian employees and the result showed that majority of the respondents answered in the affirmative. Finally, Research question four, "What is managers' opinion on the capacity, resourcefulness and potentials of the Nigerian workers?" was answered using four statements and the result showed that majority of the respondents believed in the resourcefulness of Nigerian employees. The result is illustrated in Table 1.

Table 1: Frequency Distribution of Managers' Perception of Work Behaviors among Nigerian Workers

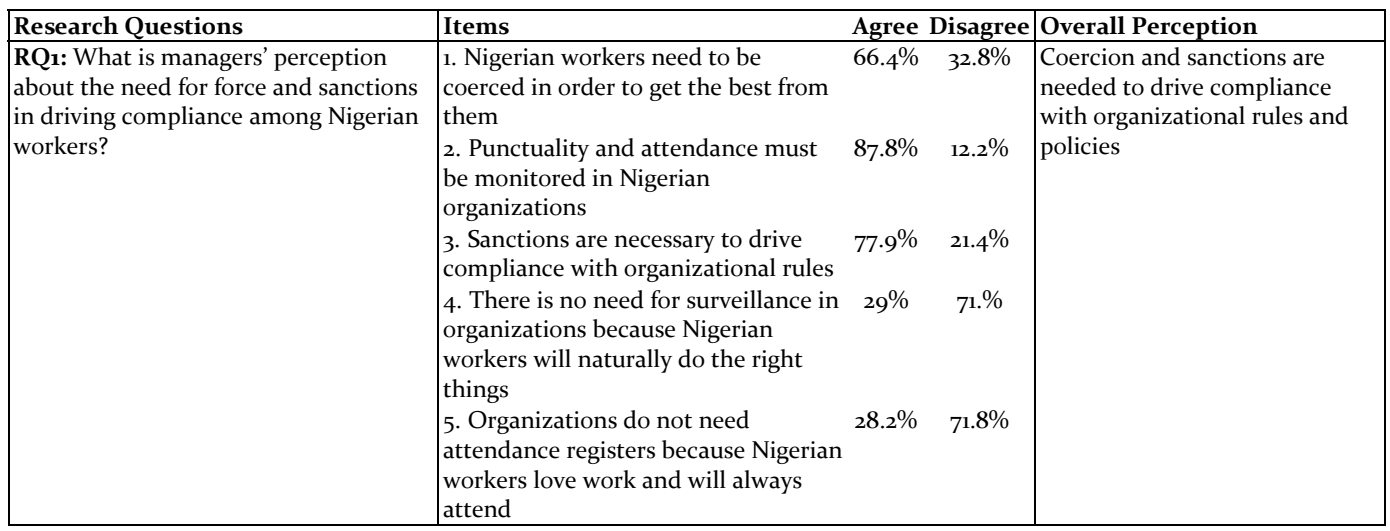




\begin{tabular}{|c|c|c|c|c|}
\hline Research Questions & Items & Agree & Disagree & Overall Perception \\
\hline \multirow{2}{*}{$\begin{array}{l}\text { RQ2: What is managers' perception } \\
\text { about the individualistic nature of } \\
\text { Nigerian workers? }\end{array}$} & $\begin{array}{l}\text { 6. An average Nigerian worker is lazy } \\
\text { and self-centered }\end{array}$ & $50.3 \%$ & $48.9 \%$ & \multirow{2}{*}{$\begin{array}{l}\text { Half of the respondents agreed } \\
\text { that Nigerian workers are self- } \\
\text { centered }\end{array}$} \\
\hline & $\begin{array}{l}\text { 7. Nigerian workers are mainly } \\
\text { motivated by self- interest and } \\
\text { personal goals }\end{array}$ & $52.7 \%$ & $47 \cdot 3 \%$ & \\
\hline $\begin{array}{l}\text { RQ3: What is managers' perception on } \\
\text { pay, rewards and benefits as the } \\
\text { primary motivators among Nigerian } \\
\text { workers? }\end{array}$ & $\begin{array}{l}\text { 8. Pay, rewards and benefits are the } \\
\text { main motivating factors for workers } \\
\text { in Nigeria }\end{array}$ & $94.7 \%$ & $5.3 \%$ & Pay is the major motivator \\
\hline \multirow[t]{4}{*}{$\begin{array}{l}\text { RQ4: What is managers' opinion on the } \\
\text { capacity, resourcefulness and potentials } \\
\text { of the Nigerian workers? }\end{array}$} & $\begin{array}{l}\text { 9. Given the right environment, } \\
\text { Nigerian workers will certainly work } \\
\text { at their best }\end{array}$ & $89.3 \%$ & $10.7 \%$ & \multirow[t]{4}{*}{$\begin{array}{l}\text { Resourceful and have capacity } \\
\text { for growth and commitment to } \\
\text { work }\end{array}$} \\
\hline & $\begin{array}{l}\text { 10. Nigerian workers enjoy } \\
\text { challenging tasks and opportunities } \\
\text { to explore their potentials }\end{array}$ & $66.4 \%$ & $33.6 \%$ & \\
\hline & $\begin{array}{l}\text { 11. Nigerian workers are resourceful, } \\
\text { cooperative and diligent }\end{array}$ & $77.1 \%$ & $22.9 \%$ & \\
\hline & $\begin{array}{l}\text { 12. Nigerian workers are capable of } \\
\text { participative decision-making and } \\
\text { mutual responsibility }\end{array}$ & $82.3 \%$ & $17 \cdot 7 \%$ & \\
\hline
\end{tabular}

\section{Discussion}

Although managers have described Nigerian employees as individualistic, they also see them as resourceful and having capacity for growth. It was generally agreed that Nigerian employees would perform at their best when presented with the right working conditions. Also, there was a consensus on the need for force and surveillance in the effective management of Nigeria workers. The Nigerian and American work cultures have some similarities; this is because Nigerians consider and adopt American work processes as the standard for global best practices. Although Theory Y is gradually gaining grounds in more ideal situations, Nigerian work culture supports Theory $\mathrm{X}$ as the most appropriate management style for Nigerian employees. As far as Nigeria is concerned, Theory Z remains an aspiration (Olowookere, 2015). Theory X was McGregor's description of traditional American management style; but the humanistic approach to management has given popularity to Theory $\mathrm{Y}$ in the American work context.

The result of the current study also showed that managers unanimously agreed that Nigerian employees are mainly motivated by pay. This may be as a result of the increased poverty in Nigeria. In corroboration, the National Bureau of Statistics (2019) have estimated the poverty rate of Nigeria at 40.09\%. Also, Maslow (1970) argued that employees' needs serve as primary motivators until such needs are satisfied. Consequently, the poverty level in Nigeria explains the reason employees are primarily motivated by pay.

Furthermore, about half of the managers believed that Nigerian workers are self-centered and only interested in self-preservation. From the results of the world ranking, America ranked highest in individualism, $1^{\text {st }}$ position, followed by Nigeria, $41^{\text {st }}$ position and the least ranked was Japan, 23rd position (Hofstede 2001, Hofstede, 1991). By implication, although Nigeria is traditionally collectivist society, Nigerians do have traits of individualism that plays out especially in work settings, Nigerians can be very competitive even in their communal lifestyle,a situation that may be described as individualism in collectivism.

Work culture influences employees work behaviors and organizational outcomes (Smrita Sinha, Singh, Gupta \& Dutt, 2010). In the pursuit of global competitiveness, every organization requires employees who will voluntarily engage in prosocial behaviors towards the achievement of organizational success (Jahangir et al, 2004). Since these behaviors cannot be enforced, it is important that organizations provide the appropriate working conditions that will stimulate such responses from employees. Infusing American cultural practices into work cultures in Nigeria have not produced the best of results, probably because adequate attention have not been given to the peculiarity of the 
Nigerian people. The combination of Theory X and Theory Y in the Nigerian work culture has at best produced committed employees and in most cases average employees (who merely comply with organizational standards). On the other hand, Japanese management style (Theory Z) may be considered the most effective management style (Ouchi, 1981) which engenders employee loyalty and as evinced by the successes of Japanese organizations compared to their American counterparts.

To this end, a model of Nigerian, and by extension, African work culture has been proposed to cater to the peculiarities of the Nigerian people. This model of work culture will combine features of Theory X, Theory Y and Theory $\mathrm{Z}$ as they relate to the Nigerian people. Japanese work culture cannot be adopted hook, line and sinker because of major cultural differences between Nigeria and Japan. Based on Hofstede's cultural dimensions and world ranking, Nigeria and Japan are very different in terms of indulgence and long term orientation. Nigerians are fun-loving and focus on the here and now while Japanese are conservative and focus on the future.

Aspects of the Japanese work culture (Theory Z) that should be incorporated into the Nigerian work culture include mutual benefits, mutual responsibilities, participative decision making and emphasis on employee welfare. Also, aspects of Theory Y that need to be incorporated into the Nigerian work culture is favorable working condition, awards and recognition of outstanding performances, employee training and development among others.

Lastly, Theory $\mathrm{X}$ seems to be reputed as being harsh and inhumane but it does serve important role in employee management in Nigeria. There are aspects of Theory $\mathrm{X}$ that must be retained in the Nigerian work culture. These aspects include the use of sanctions, performance monitoring and contingent reward for performance. Pay satisfaction is a crucial aspect of employee motivation in Nigeria and must be taken seriously in management decisions and planning. Fig.1 illustrates the blend of Theory X, Y and Z as a model of the Nigerian (African) work culture.

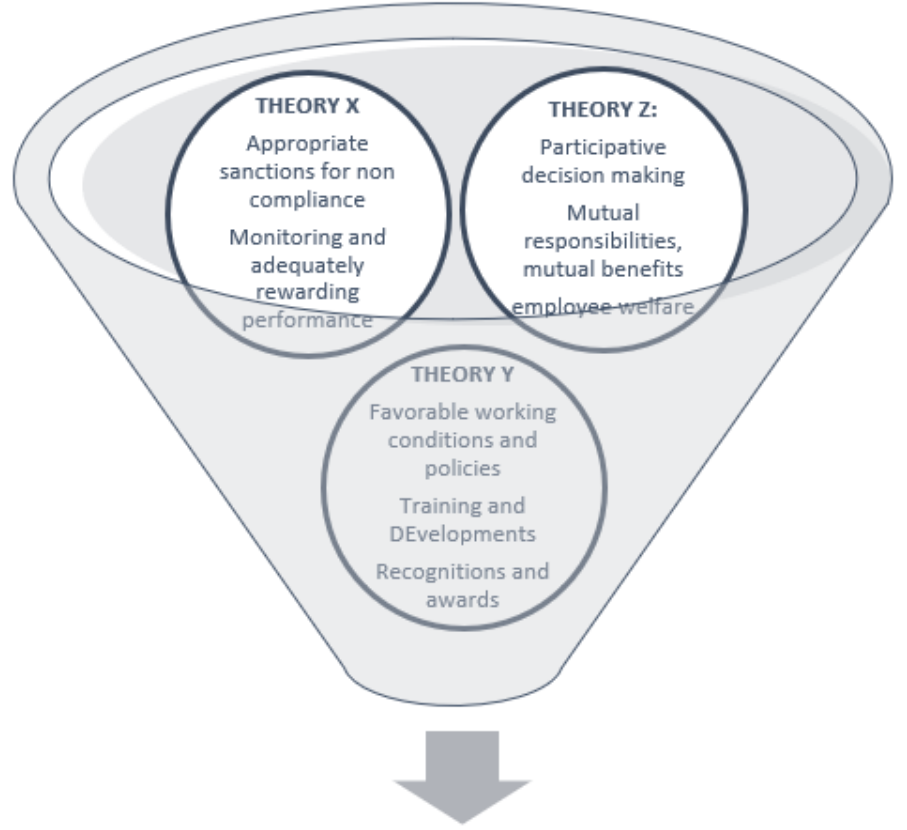

Employee loyalty and positive work behaviours

Fig. 1: A model of Nigerian (African) work culture 
A blend of Theory X, Theory Y and Theory Z management styles was proposed as crucial elements of the African work culture which will engender employee loyalty and positive work behaviors. This was based on the notion that Nigerian workers require some degree of coercion coupled with favourable work content and context for the most productive work performance.

\section{Conclusion and Recommendation}

Globalization has made it possible for nations of the world to imbibe aspects of foreign cultures that best suit their purposes. However, the quest for economic sustainability and global relevance has created opportunities for acculturation at the expense of traditional national cultures (Asikaogu, 2019). Work cultures have also been affected, with serious consequences for employees' behaviors and organizational outcomes.

An important aspect of work culture is its motivational element, the ability to attract and retain happy employees who will voluntarily go above and beyond the call of duty in the pursuit of organisational success. The effectiveness of work cultures lie in their ability to adequately cater to the needs of their employees. Although Theory $\mathrm{Z}$ appears to produce the most effective management style, Nigerian managers cannot adopt the full Japanese work culture because of cultural differences between Japan and Nigeria. Likewise, Nigeria, though similar to America in some aspects of its culture, it cannot completely adopt the American work culture because of certain peculiarities. It is therefore imperative to understand the uniqueness of the workforce before adopting aspects of foreign cultures.

The nature of the Nigerian employees is such that requires a blend of Theory X, Theory Y and Theory Z. At different levels, aspects of these Theories will be required to drive compliance and foster commitment. In conclusion, the proposed African work culture has aspects of Japanese and American work cultures integrated into the traditional African (Nigerian) culture.

Although this study provides empirical evidence on managers' assumptions about the Nigerian workforce, it has limited scope because it only sampled managers in Ota, Ogun State. There is a need to extend this study to other states of Nigeria and across sectors of the economy.

\section{Acknowledgements}

The Covenant University Centre for Research, Innovation and Discovery (CUCRID) provided the financial assistance needed to complete this study.

\section{References}

Adetola O. B; Ogunbote G; Omonijo, D. O and Odukoya. J. A (2019). Circumcisions and Related Practices about Childbirth in Sagamu, Ogun State, Nigeria. Academic Journal of Interdisciplinary Studies, 8(4): 78-9o. https://doi.org/.10.36941/ajis-2019-0010

Akinbode, G.A., \& Fagbohungbe, O.B. (2012). Leadership and organizational factors as predictors of employees' organizational commitment in Nigeria: An Empirical Analysis. Business and Management Research, 1(2), 7087.

Asikaogu, J, (2018). Igbo Cultural Values and the Effect of Globalization: A Critical Analysis. ARCN International Journal of Social Sciences and Humanities ISSN: 2384-8942, 12(2), 42 -51.

Bannon, G., Guy, V., Al-Omari, J., Reed, B., Pooley, R., \& White, N. (2003). Cross-cultural communication: the essential guide to international business (J. Mattock, Ed.) London: Kogan Page.

Hofstede, G. (1991). Culture and organizations. Software of the mind. London, UK: McGraw Hill.

Hofstede, G. (2001). Culture's consequences: Comparing values, behaviors, institutions, and organizations across nations. Second Edition. Thousand Oaks CA: Sage Publications.

Hofstede, G. (2011). Dimensionalizing Cultures: The Hofstede Model in Context. Online Readings in Psychology and Culture, 2(1). https://doi.org/10.9707/2307-0919.1014

Jahangir, N., Akbar, M.M., \& Haq, M. (2004). Organizational citizenship behaviour: Its nature and antecedents. BRAC University Journal, I (2),75-85.

Maslow, A. H. (1970). Motivation and Personality. New York: Harper \& Row. 
Mbah S. E. \& Kuye O.L. (2019). Cross-cultural Human Resource Management Practices: The Case of Nigeria, USA and Japan.E-Journal of international and comparative labour studies, 6(2), 77-96.

McGregor, D. (1960). The Human Side of the Enterprise. New York: McGraw-Hill, Inc.

National Bureau of Statistics (2019). JUST IN: 82.9 Million Nigerians Living In Poverty. Sahara Reporters. Retrieved from http://saharareporters.com/2020/05/04/just-829-million-nigerians-living-poverty--nbs-report

Pfeffer, P. (1998). The human equation: Building profits by putting people first.Harvard Business School Press:Boston, MA

Rudd, J. E., \& Lawson, D. (2007). Communicating in global business negotiations a geocentri approach. Los Angeles: Sage Publications.

Odogwu, C. (2012). Creating a productive organizational culture in Nigeria. Retrieved from http://www.nigeria36o.com/creating-a-productive-organizational-culture-in-nigeria/

Oludayo, A.O \& Omonijo, D. O. (2020). Work-life Balance: Relevance of Social Support. Academy of Strategic Management Journal, 9(3): 1-10. 1939-104-19-3-557

Omonijo, D. O \& Anyaegbunam, M. C. (2020). Exploring The Concept of Social Change in the Thought of Ibn Khaldun. StudiesAcademic Journal of Interdisciplinary, 9(5): 292-303. https://doi.org/10.36941/ajis-2020-0105

Ouchi, W. (1981). Theory Z. America: Addison-Wesley Publishing Company

Sinha, S., Singh, A.K., Gupta, N \& Dutt, R. (2010). Impact of work culture on motivation and performance level of employees in private sector companies. Acta Oeconomica Pragensia,18(6), 48-67.

Weaver, G.R. (2005). Culture, communication and conflict. Intercultural Management Institute.

Wysocki, A. F., \& Kepner, K. W. (2000). Human resources management in agric-business. A Publication of the Department of Food and Resource Economics, Florida Cooperative Extension Service, Institute of food and Agricultural science, University of Florida, Gainesville, Florida. 